Original Research Article

\title{
Prevalence of biofilm controlling ica genes of Staphylococcus epidermidis detected in healthy skin, blood samples from septicaemia patients and chronic wounds
}

\author{
Malik Asif Hussain $^{1,2}$, Irani Udeshika Rathnayake ${ }^{1,2}$, Flavia Huygens ${ }^{1,2 *}$
}

\author{
${ }^{1}$ Infection and Immunity \\ Program, Institute of Health and \\ Biomedical Innovation, \\ Queensland University of \\ Technology (QUT), Brisbane, \\ Australia \\ ${ }^{2}$ Wound Management \\ Innovation Co-operative \\ Research Centre, Brisbane, \\ Australia
}

Received: 20 October 2016

Accepted: 17 November 2016

*Correspondence to:

Dr. Flavia Huygens,

Email: f.huygens@qut.edu.au

Copyright: () the author(s), publisher and licensee Medip Academy. This is an openaccess article distributed under the terms of the Creative Commons Attribution NonCommercial License, which permits unrestricted noncommercial use, distribution, and reproduction in any medium, provided the original work is properly cited.

\begin{abstract}
Background: The role of microbes in the persistence of chronic wounds is very important. Biofilm mode of bacterial growth has been found to be clinically very important in various types of infections. Bacterial growth in the form of biofilm is now being considered as a strong and effective mechanism of bacterial survival and growth in chronic wounds. Therefore it is clinically important to further investigate and determine the bacterial groups involved in the formation of biofilm in wounds and their mechanism of interference with the normal healing process.

Methods: This study focussed on determining the presence of S. epidermidis ica genes, which are responsible for biofilm production by this species. We investigated the presence of these genes in skin, blood and wound samples. In total, 296 samples were tested for the presence of the ica genes. RT-PCR and conventional PCR testing was performed on these samples from different sources.

Results: Our results show that there is presence of a significant number of ica positive samples both in skin and blood specimens while only a very small percentage of ica positive samples present in chronic non-healing wound samples.

Conclusions: Presence of ica genes in blood samples indicate involvement of ica positive $S$. epidermidis in the case of blood infection. In chronic wound samples, there is a small percentage of samples positive for these genes thus biofilm producing bacteria other than $S$. epidermidis are likely to be more important in the case of chronic wounds.
\end{abstract}

Keywords: Biofilm, Chronic wounds, Ica genes, Septicaemia, S. epidermidis

\section{INTRODUCTION}

Biofilms are widely distributed in the natural world such as dental plaques, water pipes and congregates in flowing water bodies. ${ }^{1}$ Biofilm can form on both biotic and abiotic surfaces such as catheters, artificial valves, contact lenses and other types of implants. Similarly, clinical conditions such as chronic wounds, osteomyelitis, periodontitis and chronic otitis media also develop biofilm, even in the absence of any foreign device. ${ }^{2,3}$
Clinically, the biofilm mode of bacterial growth is more important than free-floating bacterial colonization or infection as this is more tolerant to antimicrobials. ${ }^{4}$ Recent studies have indicated the role of biofilm in chronic wound development and persistence. ${ }^{5}$

Stoodley has defined the biofilm as a "sessile community of bacteria that are irreversibly attached to a surface or to each other, live in clusters embedded within a matrix of extracellular polymeric substance that they have 
produced, and exhibit an altered phenotype with respect to gene transcription". 6 Multiple species of bacteria reside in a synergistic manner in the form of a biofilm and contribute to produce a subclinical and prolonged infection. $^{7}$ Biofilms mainly consist of bacteria and extracellular polymeric substance (EPS) produced by these bacteria to form a complex three dimensional structure. Bacteria usually constitute $5-25 \%$ of a biofilm's overall structure, while $75-95 \%$ is made up of EPS. ${ }^{2,8}$

Biofilm development is a complex process which involves many metabolic chemicals, environmental signals and substances, and signal transduction pathways. ${ }^{9}$ Attachment, maturation and dispersal have been described as stages of biofilm development. The initial attachment stage involves attachment of planktonic bacteria and utilizes chemicals and proteins (adhesins) originating from both the host and bacteria. ${ }^{10}$ The second stage of maturation consists of bacterial growth along with EPS production. Substances present in EPS play a vital role in attaching these bacteria to host surfaces as well as to each other. Different substances such as proteins, lipids, polysaccharides and nucleic acids are the main components of EPS. ${ }^{11,12}$ Finally, cells from biofilm growth detach and disperse. This final stage is important in disease transmission and survival. ${ }^{10}$

\section{Indwelling devices, biofilm and septicaemia}

Biofilm is a very useful and powerful factor contributing to device related infections. ${ }^{13}$ Initial adhesion and aggregation of microbes onto multiple layers is followed by biofilm formation. There is a view that before the actual process of biofilm development and formation, the surfaces of indwelling devices are "conditioned" in vivo. Different components present in body secretions such as saliva, mucus and urine form a coat by adsorbing on the surfaces of devices to form a conditioning layer or film upon which actual bacterial growth and biofilm formation occurs. ${ }^{14}$ This conditioning film acts as an attaching surface for bacteria. ${ }^{15}$ Another view is that this primary adhesion is dependent on the chemistry of the material used for implanted devices, which also affects other processes including biofilm formation and its thickness. ${ }^{16}$ Dunne has described other factors such as electrostatic and hydrophobic interactions, Van der Walls forces and temperature that also impact on biofilm formation. ${ }^{17}$ Biofilms play a vital role in pathogenesis and plays a significant part in morbidity and mortality in device related infections and resulting septicaemia. ${ }^{18,19}$

\section{The role of biofilms in chronic wound prognosis}

Clinicians treating wound infections are now considering biofilm as a major factor in non-healing wounds and staphylococci are the commonest bacteria present on wound surfaces. $^{20-22}$ In describing the role of biofilm in chronic wounds, Bowler have defined it as "communities of microorganisms attached to a surface (e.g. wound tissue, wound dressings), embedded within a hydrated matrix of extracellular polymeric substances (EPS; or slime), that provides protection against antimicrobial agents and host defences". 20 The presence of biofilm typically presents with progressive infections which are resistant to antibiotics and immune system eradication. ${ }^{19,23}$ Most of the routine treatment methods fail in the presence of biofilm. ${ }^{24}$ Although the physical removal of biofilm is important, it can quickly reform within hours. Hence, it is very important to avoid the biofilm reforming by applying appropriate wound dressing, debridement and antibiotics. ${ }^{25}$

James and colleagues found a significant difference in acute and chronic wounds in terms of biofilm presence, reporting $6 \%$ and $60 \%$ positivity, respectively. ${ }^{26}$ However, the precise role of biofilm in chronic wounds is not known. One proposed mechanism for interference of biofilm with wound healing is by prolonging the inflammatory phase of wound healing, which is also called sustained hyper-inflammation. This sustained inflammation maintains a continuous supply of exudates in the wound bed which maintains continuous feeding requirements of biofilm forming bacteria. ${ }^{27}$

In a recent in vitro study by Gawande and co-workers, they found that a therapeutic plan involving the breakdown of preformed biofilm and inhibiting its formation or regrowth, along with broad-spectrum antimicrobial therapy, is an effective method to treat biofilm related infections. ${ }^{23}$ Diagnosis and confirmation of biofilm presence in chronic wounds is very important and requires further investigation. ${ }^{20,28}$ Biofilm impaired wound healing might be treated more successfully if we understand how the innate immune system is affected, followed by an approach to target biofilm for the treatment of chronic wounds. ${ }^{29}$

\section{Staphylococci and ica genes}

Staphylococci are known to produce biofilm..$^{30,31}$ Coagulase-negative staphylococci (CoNS) such as $S$. epidermidis can cause serious hospital acquired infections and is a biofilm producing species. ${ }^{32}$ Most common victims of $S$. epidermidis infection are premature newborns, patients with leukaemia, intravenous drug abuse, other malignancies and patients with indwelling polymer bodies, such as prosthetic devices or intravenous catheters. $^{33,34}$

The extracellular Polysaccharide Adhesins (PSA) is a significant virulence determinant and is required for biofilm formation and adhesion, which is encoded by the ica operon, and is subjected to phase variable regulation, and an on and off switching mechanism. ${ }^{35}$ Polysaccharide intercellular adhesin (PIA) is the main component involved in intercellular adhesion by staphylococci. ${ }^{32,36}$ Stevens et al studied various protein components including PIA of biofilm in S. epidermidis and have suggested that PIA has a primary role in biofilm positivity while protein components contribute 
significantly towards the maturation of the biofilm. ${ }^{37,38}$ PIA synthesis requires the presence of the ica operon because the enzymes which are involved in its synthesis are controlled by the intercellular adhesion operon (ica ADBC). ${ }^{37,38}$ Biofilm studies have used oral biofilm as research models for some time and its characteristics and pathogenesis have been studied. On the other hand, recent studies have indicated the role of biofilm in chronic wound development and persistence. , 20,21,39 $^{-1}$

Understanding the role of biofilm and determination of its relation to wound chronicity will be very beneficial in terms of wound treatment and wound management strategies. ${ }^{9}$ Bacterial colonization in the form of biofilm is associated with delays in wound healing. However, there is still a need to investigate the exact role of biofilm in delaying wound healing and the development of antibiofilm mechanisms to control infections. ${ }^{40}$

This study aims to detect of ica genes of $S$. epidermidis in skin, blood and wound samples. We detected a significant presence of ica genes in skin as well as in blood samples. As wounds are potentially at risk of becoming colonized by skin microbes, we tested chronic wound samples for the presence of these genes to determine if ica positive $S$. epidermidis is a major biofilm producer in the case of chronic non-healing wounds.

\section{METHODS}

\section{Samples}

Three different types of samples have been included in this study:

1. Swabs were taken from the skin of healthy individuals and pure cultures of CoNS strains were isolated from these samples.

2. Coagulase negative staphylococcal isolates originating from patients with septicemia. These strains were cultured and isolated from patients from the Prince Charles (PC) Hospital, Brisbane.

3. Chronic wound swab samples were obtained from the Queensland University of Technology (QUT) Wound Clinic, Brisbane.

\section{Skin swab samples}

Swab samples were collected from the skin of healthy individuals (volunteer second and third year undergraduate students at QUT). Ethical approval for collecting these samples from humans was obtained from the QUT Human Research Ethics Committee. In addition, written consent was obtained from each participant in the study. Skin samples were inoculated on a selective medium for staphylococci i.e. Mannitol Salt Agar (MSA). Plates were incubated at $37^{\circ} \mathrm{C}$ for 24 hours. These strains were subcultured onto NA plates using the 16-streak method. After overnight incubation, the Staphylase test (Sigma-Aldrich®, USA) was performed on each of the isolates to confirm the coagulase test. Strains that tested staphylase-negative were used for further investigation. Subsequently, 12-15 colonies from each plate were suspended in Lysostaphin solution $(200 \mu \mathrm{g} / \mathrm{ml}$; SigmaAldrich, USA) and incubated at $37^{\circ} \mathrm{C}$ for 30 minutes. After 30 minutes of incubation this mixture was ready for DNA extraction.

\section{Hospital septicaemia patient samples}

Patient cultures were acquired from the Prince Charles Hospital. The isolates identified as CoNS strains were stored on Nutrient Agar (NA) slopes (Biomérieux, Australia) at a temperature of $4{ }^{\circ} \mathrm{C}$. These strains were subcultured onto NA plates using the 16-streak method. Plates were incubated at $37^{\circ} \mathrm{C}$ for 24 hours. After overnight incubation, 12-15 colonies were selected from each plate and were suspended in $180 \mu \mathrm{l}$ of Lysostaphin solution $(200 \mu \mathrm{g} / \mathrm{ml})$. This suspension was incubated at $37^{\circ} \mathrm{C}$ for 30 minutes. After 30 minutes of incubation this mixture was ready for DNA extraction.

\section{Wound swab samples}

Wound swab samples were collected at the QUT wound clinic. A total of 207 wound swabs from 38 chronic wound patients were included in this study using the Ztechnique. The swabs were collected over a period of 12 weeks, when patients visited the QUT wound clinic for wound treatment. These samples were assigned codes to avoid revealing patient identity. QUT ethics approval for this project is included in: project approval number 1000001255. Non-healing (chronic) patients were assigned using a Pressure Ulcer Scale for Healing (PUSH) score, as set by the National Pressure Ulcer Advisory Panel (www.npaup.org/wpcontent/uploads/2012/02/push3.pdf). Patients with a PUSH score of more than 2 at the $24^{\text {th }}$ week were included in this study. Wound swabs were stored at $80^{\circ} \mathrm{C}$, until further use.

\section{DNA extraction}

DNA extraction from skin, septicemia patient isolates and chronic wound patient swab samples was done using the DNeasy ${ }^{\circledR}$ Blood and Tissue Kit (QIAGEN®, Australia) using the protocol described by Price and coworkers with modifications which involved both physical and enzymatic lysis steps. ${ }^{41}$ Briefly, frozen wound swabs were allowed to thaw at room temperature and suspended in $300 \mu 1$ of Ultra-pure DNAse- RNAse free water (Roche, Australia) and 50ul of lytic enzyme mix. A lytic enzyme mix was prepared fresh at the time of extraction and consists of $40 \mu \mathrm{l} / \mathrm{ml}$ of Lysostaphin (Sigma, Australia), 20mg/ml of Lysozyme (Sigma, Australia) and $100 \mathrm{U} / \mathrm{ml}$ of Mutanolysin (Sigma, Australia). Samples were digested by incubating for 30 minutes at $37^{\circ} \mathrm{C}$ in a dry heating block. After centrifugation at $1500 \mathrm{rpm}$ for 1 minute, the solution was transferred into a bead-beating tube (MoBio, Carlsbad, CA). Bead beating (Mini- 
Beadbeater-24, Biospec Products, Bartlesville, OK) was carried out at $1500 \mathrm{rpm}$ for 1 minute flowed by centrifugation at $1200 \mathrm{rpm}$ for 1 minute. The crude lysate was transferred to a sterile microfuge tube containing Qiagen Buffer AL (Qiagen, Australia) and vortexed for 15 seconds. This was followed by 10 minute incubation at $56^{\circ} \mathrm{C}$ and centrifugation at $1500 \mathrm{rpm}$ for 1 minute. After this step, further DNA purification was done using the QIAmp DNA purification kit using blood or body fluids protocol (spin protocol) as per manufacturer's instructions (Qiagen, Australia). The extracted genomic DNA quality and quantity was measured using the NanoDrop Spectophotometer (Biolab, Australia) and the DNA was stored at $-80^{\circ} \mathrm{C}$ until further use. For skin and septicaemia patient isolates, protocol for gram-positive bacteria as per manufacturer's instructions (Qiagen, Australia) was followed and extracted DNA was stored at $-80^{\circ} \mathrm{C}$.

\section{Primers and PCR cycling conditions}

For the detection of the ica operon in hospital (septicaemia patients) and skin samples primers listed in Table 1 were used. ${ }^{42,43}$ Primers were obtained from Sigma-Aldrich®, Australia. Conventional PCR was performed on all isolates from patients and healthy individuals. This was followed by agarose gel $(2 \%)$ electrophoresis. A 100 bp DNA molecular weight marker (Bioline®, Australia) was used for comparison and analysis (Table 1).

Table 1: Primer sequences for ica genes.

\begin{tabular}{|c|c|c|}
\hline Primers & Sequence (From 5' to 3') & Product (bp) \\
\hline $\begin{array}{l}\text { icaA } \\
\text { forward } \\
\text { icaA } \\
\text { reverse }\end{array}$ & $\begin{array}{l}\text { GAC CTC GAA GTC } \\
\text { AAT AGA GGT } \\
\text { CCC AGT ATA ACG } \\
\text { TTG GAT ACC }\end{array}$ & 814 \\
\hline $\begin{array}{l}\text { icaB } \\
\text { forward } \\
\text { icaB } \\
\text { reverse }\end{array}$ & $\begin{array}{l}\text { ATG GCT TAA AGC } \\
\text { ACA CGA CGC } \\
\text { TAT CGG CAT CTG } \\
\text { GTG TGA CAG }\end{array}$ & 526 \\
\hline $\begin{array}{l}\text { icaC } \\
\text { forward } \\
\text { icaC } \\
\text { reverse }\end{array}$ & $\begin{array}{l}\text { ATA AAC TTG AAT } \\
\text { TAG TGT ATT } \\
\text { ATA TAT AAA ACT } \\
\text { CTC TTA ACA }\end{array}$ & 989 \\
\hline $\begin{array}{l}\text { icaD } \\
\text { forward } \\
\text { icaD } \\
\text { reverse }\end{array}$ & $\begin{array}{l}\text { AGG CAA TAT CCA } \\
\text { ACG GTA A } \\
\text { GTC ACG ACC TTT } \\
\text { CTT ATA TT }\end{array}$ & 371 \\
\hline
\end{tabular}

For each reaction $1 \mu 1$ for each of forward and reverse primers was mixed with $5 \mu 1$ of MyTaq Red Buffer and $1 \mu 1$ of MyTaq HS Polymerase. $2 \mu 1$ of DNA template and DNAse/RNAse free water was then added to make a total reaction volume of $25 \mu \mathrm{l}$. No addition of dNTPs and loading dye (for gel electrophoresis) is required as the $5 \mathrm{x}$ MyTaq Red Buffer contains both dNTPs and loading dye. No addition of dNTPs is required as the 5xMyTaq Red Buffer contains dNTPs. No loading dye is required for gel electrophoresis as this is also included in the $5 \mathrm{x}$ MyTaq Red Buffer. Each sample was amplified using a PCR cycling procedure as follows: $95^{\circ} \mathrm{C}$ for 3 minutes, followed by 30 cycles of $94^{\circ} \mathrm{C}$ for 30 seconds, $57^{\circ} \mathrm{C}$ (icaA) $/ 65^{\circ} \mathrm{C}($ icaB $) / 43^{\circ} \mathrm{C}($ ica $\mathrm{C}) / 65^{\circ} \mathrm{C}($ ica $\mathrm{D})$ for 30 seconds and $72{ }^{\circ} \mathrm{C}$ for 10 minutes. These PCR reactions were run on a Mastercycler PCR engine (Eppendorf ${ }^{\circledR}$, Australia).

A $2 \%$ agarose gel was used for electrophoresis, with a Tris-Borate-EDTA (TBE) running buffer. A 100 bp DNA molecular weight marker (Bioline $\AA$, Australia) was used for analysis. Figure 1 depicts the ica $\mathrm{D}$ detection as an example (Figure 1).

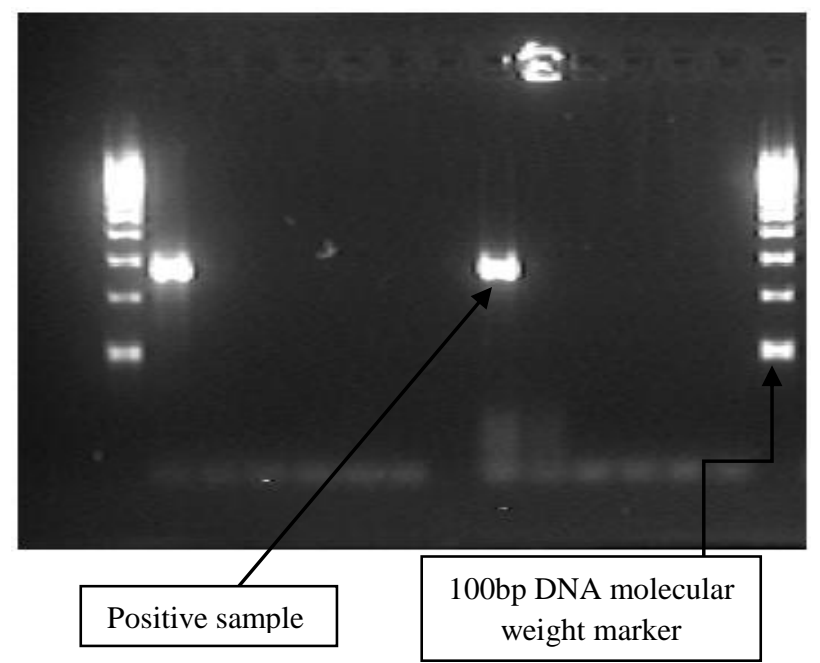

Figure 1: A 2\% agarose gel showing the presence of the icaD gene in two $S$. epidermidis isolates.

For wound samples, Real-Time PCR was performed. For $i c a \mathrm{~A}$ and $i c a \mathrm{C}$, primers were designed using the Primer Express software (Applied Biosystems, USA). See Table 2 below for details. For icaB and ica $\mathrm{D}$ same primers designed for testing skin and blood samples were used (Table 1). The Rotor-Gene 6000 instrument was used for RT-PCR experiments (QIAGEN, Australia) (Table 2).

Table 2: Primer sequences for ica gene detection in wound samples.

\begin{tabular}{|c|c|c|}
\hline Primers & Sequence (From 5' to 3') & Product (bp) \\
\hline $\begin{array}{l}i c a \mathrm{~A} \\
\text { forward } \\
i c a \mathrm{~A} \\
\text { reverse }\end{array}$ & $\begin{array}{l}\text { GTC ATT GAT GAC } \\
\text { GAT GCG CC } \\
\text { CTT GAG CCC ATC } \\
\text { GAA CCC TT }\end{array}$ & 397 \\
\hline $\begin{array}{l}\text { ica } \mathrm{C} \\
\text { forward } \\
\text { icaC } \\
\text { reverse }\end{array}$ & $\begin{array}{l}\text { ATC GCT GTT TCC } \\
\text { GGT AGT GAT } \\
\text { CTC TTA ACA TCA } \\
\text { TTC CGA CGC C }\end{array}$ & 297 \\
\hline
\end{tabular}

For each reaction $1.25 \mu$ l of each forward and reverse primer was added to $10 \mu \mathrm{l}$ of Sybr Green mastermix (Life Technologies, Australia) and $5.5 \mu \mathrm{l}$ of DNAse/RNAse 
free water (Roche, Australia). $2 \mu$ l of DNA extract was added to a total reaction volume of $20 \mu$ l.

Each reaction was amplified using a three step Real-Time PCR cycling procedure as follows: Hold for 2 minutes at $50^{\circ} \mathrm{C}$, then at $95^{\circ} \mathrm{C}$ for 10 minutes, followed by 40 cycles of $95^{\circ} \mathrm{C}$ for 10 seconds, a specific annealing temperature for each primer $\left(57^{\circ} \mathrm{C}(\right.$ icaA $) / 65^{\circ} \mathrm{C}($ icaB $) / 43^{\circ} \mathrm{C}($ ica $\mathrm{C})$ $165^{\circ} \mathrm{C}($ ica $\mathrm{D})$ ) for 20 seconds and $72^{\circ} \mathrm{C}$ for 30 seconds. After the 40 PCR cycles, the DNA amplicons were subjected to a hold at $72^{\circ} \mathrm{C}$ for 5 minutes and followed by a melt step ramping from $72^{\circ} \mathrm{C}$ to $95^{\circ} \mathrm{C}$ rising by $1^{\circ} \mathrm{C}$ and waiting for 90 seconds for pre-melt conditioning on the first step only, followed by a 5 second wait for each step thereafter. Following the melt step, a High Resolution Melt (HRM) step was performed by ramping from $50^{\circ} \mathrm{C}$ to $99^{\circ} \mathrm{C}$, rising by $0.1^{\circ} \mathrm{C}$ at each step, waiting for 90 seconds for pre-melt conditioning on the first step only, followed by a 2 second wait for each step thereafter. The Rotor-Gene 6000 instrument was used for all experiments (Corbett Life Science, now QIAGEN, Australia). Two reference strains of S. epidermidis, the ATCC 35984 (biofilm-producing) and the ATCC 12228 (non-biofilmproducing) were used for RT-PCR analysis as positive and negative control respectively.

\section{RESULTS}

Different studies have reported the presence of Staphylococcus sp., Pseudomonas sp., Anaerococcus sp., Enterococcus sp., Finegoldia sp., Proteus sp., Prevotella $\mathrm{sp}$., Stenotrophomonas sp., Citrobacter sp. Serratia sp. and Enterobacter sp. residing in wound beds. ${ }^{26,44,45}$ Based on the prevalence of staphylococci as the most abundant genera in previous studies mentioned above, as well as our bacterial diversity results (unpublished data) and the importance of $S$. epidermidis biofilm producing genes, we decided to determine the presence of ica genes in wound samples and compare it to blood and skin samples.

The presence of the ica genes plays an important role in the pathogenicity of $S$. epidermidis and other CoNS and are involved in the production and expression of various structures such as PIA, biofilm and autolysin. ${ }^{46,47}$ In total, 296 samples were tested for the presence of the ica genes (ADBC). Of these, 48 samples (in the form of bacterial cultures) were from patients with septicaemia, 41 samples were cultured from the skin of healthy individuals whereas the remaining 207 swab samples were obtained from chronic wound patients.

Amongst the septicaemia patient isolates, $25 \%$ tested positive for the presence of icaA, $20.83 \%$ for icaB, 33.33 $\%$ for $i c a \mathrm{C}$ and $29.16 \%$ for icaD. From the 41 skin isolates, the same percentage of ica $\mathrm{A}$, icaB and ica $\mathrm{D}$ genes i.e. $19.51 \%$ was detected while $24.39 \%$ had the icaC gene present. Finally, $3.38 \%$ of wound samples had $i c a \mathrm{~A}, 2.41 \%$ had $i c a \mathrm{C}$ and $4.34 \%$ had ica $\mathrm{D}$ while ica $\mathrm{B}$ was not detected in these samples. Figure 2 depicts a comparison of samples from all the sources in terms of various ica gene positivities (Figure 2).

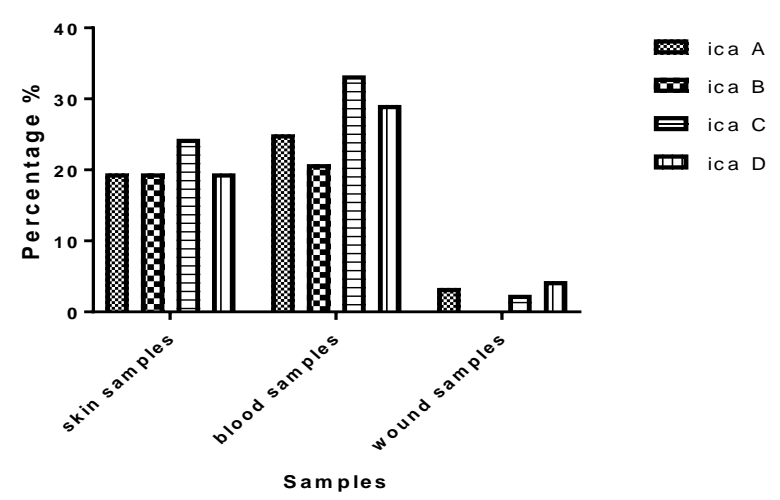

\section{Figure 2: Prevalence of the four ica genes in skin, blood and wound samples.}

Table 3 shows the number of samples that tested positive for each of the four ica genes in all three sample sources (Table 3).

Table 3: Comparison of ica genes present in skin, blood and wound samples.

\begin{tabular}{|c|c|c|c|c|}
\hline $\begin{array}{l}\text { Biofilm } \\
\text { gene }\end{array}$ & & $\begin{array}{l}\text { Skin } \\
\text { Samples }\end{array}$ & $\begin{array}{l}\text { Blood } \\
\text { Samples }\end{array}$ & $\begin{array}{l}\text { Wound } \\
\text { Samples }\end{array}$ \\
\hline \multirow{3}{*}{$i c a \mathrm{~A}$} & Presence & 8 & 12 & 7 \\
\hline & Absence & 33 & 36 & 200 \\
\hline & Total & 41 & 48 & 207 \\
\hline \multirow{3}{*}{$i c a \mathrm{~B}$} & Presence & 8 & 10 & 0 \\
\hline & Absence & 33 & 36 & 207 \\
\hline & Total & 41 & 48 & 207 \\
\hline \multirow{3}{*}{$i c a \mathrm{C}$} & Presence & 10 & 16 & 5 \\
\hline & Absence & 31 & 32 & 202 \\
\hline & Total & 41 & 48 & 207 \\
\hline \multirow{3}{*}{$i c a \mathrm{D}$} & Presence & 8 & 14 & 9 \\
\hline & Absence & 33 & 34 & 198 \\
\hline & Total & 41 & 48 & 207 \\
\hline
\end{tabular}

The interpretations are as follows:

All four genes are present in almost the same percentages in both skin and blood samples indicating that the same genes are present in healthy skin samples and septicaemia patient blood samples. It could be interpreted that ica containing strains of bacteria which are usually present on the skin of healthy people are possibly involved in septicaemia in patients with indwelling devices.

Furthermore, we tested wound samples for the presence of these genes. A very small number of these samples tested positive for the presence of the ica genes. It could be interpreted that the ica containing bacterial strains are not present in the wound bed in a significant number of 
patients although, as described above, this is the opposite for septicaemia patients.

\section{DISCUSSION}

This is one of the pioneer studies reporting S. epidermidis ica gene detection in chronic wound samples. We have found that these genes are present in a significant number in skin samples indicating that as a part of normal skin flora $S$. epidermidis still possesses these genes. Then we have found a significant number of septicaemia patients with ica positive $S$. epidermidis in their blood. This is indicative of the involvement of these bacteria in septicaemia as an opportunistic pathogen. The mechanism in this case is most likely colonization of indwelling devices such as cannulas and catheters in these hospitalized patients with subsequent spread of infection to the blood stream.

We detected a very low percentage of these genes in chronic wound swab samples compared to skin and blood samples. We propose that ica positive $S$. epidermidis is not a major species present on chronic wounds which could cause biofilm formation. Thus we are suggesting further investigating the presence of other biofilm producing bacterial species. Our results indicate that $S$. epidermidis strains harbouring the ica genes, is not present in large percentages in chronic wounds.

There are other biofilm producing bacteria that could be involved. For example, Pseudomonas species and other Staphylococcus species such as MRSA are well known for biofilm formation..$^{20,24,48}$ Furthermore, with advanced molecular techniques, anaerobic bacteria are also being reported as an important group involved in wound bioburden and play a role in wound chronicity and produce biofilm. ${ }^{48,49} P$. aeruginosa causes biofilm related clinical infections, for example, it causes urinary tract infections by growing on the surface of catheters in the form of biofilm. PEL, PSL and alginate polysaccharides are produced by $P$. aeruginosa which harbour the pel, psl and alg genes, respectively. It has been shown that PEL and PSL polysaccharides are involved in biofilm production in vitro. In vivo, either one or a combination of these operons control biofilm production. It is interesting that strains lacking these genes can still form biofilm in vivo through mechanisms not requiring these polysaccharides or genes. ${ }^{48}$

Frank and colleagues have studied the effect of ten known anti-staphylococcal agents measuring both planktonic minimum inhibitory concentrations (MICs) and minimum biofilm eliminating concentrations (MBECs) against S. lugdunensis isolated from patients with various clinical infections. ${ }^{50}$ The results show susceptibility of planktonic bacteria to all of the agents while biofilm growth was resistant to high concentrations of the majority of these antimicrobials. This clearly indicates the resistance/tolerance of biofilm against antibiotics. ${ }^{50}$ Overall, wound biofilm needs further research and studies. There is need to precisely determine the bacterial species involved in biofilm production in the case of chronic wounds. The mechanism of interference of biofilm with wound healing also needs to be further clarified.

\section{ACKNOWLEDGEMENTS}

We acknowledge the support of the Wound Management Innovation Co-operative Research Centre (WMICRC) for this project. We are also grateful to QUT for providing scholarship funding for this research study.

Funding: We acknowledge the financial support of the Wound Management Innovation Co-operative Research Centre (WMICRC) for this research

Conflict of interest: None declared

Ethical approval: The study was approved by the QUT Human Research Ethics Committee

\section{REFERENCES}

1. Bradley BH, Cunningham M. Biofilms in chronic wounds and the potential role of negative pressure wound therapy: an integrative review. J Wound Ostomy Continence Nurs, 2013;40(2):143-9.

2. Chen L, Wen YM. The role of bacterial biofilm in persistent infections and control strategies. Int J Oral Sci. 2011;3(2):66-73.

3. Pöllänen MT, Paino A, Ihalin R. Environmental stimuli shape biofilm formation and the virulence of periodontal pathogens. Int $\mathrm{J}$ Mol Sci. 2013;14(8):17221-37.

4. de Oliveira A. Antimicrobial Resistance Profile of Planktonic and Biofilm Cells of Staphylococcus aureus and Coagulase-Negative Staphylococci. J Int of Mol Sci. 2016;17(9):1423.

5. Ramage G. Are we any closer to beating the biofilm: novel methods of biofilm control. Curr Opin Infect Dis. 2010;23(6):560-6.

6. Stoodley P. Biofilms as complex differentiated communities. Annu Rev Microbiol. 2002;56:187209.

7. Dowd SE. Polymicrobial nature of chronic diabetic foot ulcer biofilm infections determined using bacterial tag encoded FLX amplicon pyrosequencing (bTEFAP). 2008;3(10):e3326.

8. Hoiby N. The clinical impact of bacterial biofilms. Int J Oral Sci. 2011;3(2):55-65.

9. Mancl KA, Kirsner RS, Ajdic D. Wound biofilms: lessons learned from oral biofilms. Wound Repair Regen. 2013;21(3):352-62.

10. Kaplan JB. Biofilm dispersal: mechanisms, clinical implications, and potential therapeutic uses. J Dent Res. 2010;89(3):205-18.

11. Flemming HC, Wingender J. The biofilm matrix. Nat Rev Microbiol. 2010;8(9):623-33.

12. Darby I. Non-surgical management of periodontal disease. Aust Dent J. 2009;54(1):S86-95. 
13. Beloin C, Fernández-Hidalgo N, Lebeaux D. Understanding biofilm formation in intravascular device-related infections. Int Care Med; 2016:1-4.

14. Choong S, Whitfield H. Biofilms and their role in infections in urology. BJU Int. 2000;86(8):935-41.

15. Fitzpatrick F, Humphreys H, O'Gara JP. The genetics of staphylococcal biofilm formation--will a greater understanding of pathogenesis lead to better management of device-related infection? Clin Microbiol Infect. 2005;11(12):967-73.

16. Patel JD. S. epidermidis biofilm formation: effects of biomaterial surface chemistry and serum proteins. J Biomed Mater Res A. 2007;80(3):742-51.

17. Dunne WM. Bacterial adhesion: seen any good biofilms lately? Clin Microbiol Rev. 2002;15(2):15566.

18. Traba C, Liang JF. Bacteria responsive antibacterial surfaces for indwelling device infections. J Cont Rel. 2015;198:18-25.

19. Chen M, Yu Q, Sun H. Novel strategies for the prevention and treatment of biofilm related infections. Int J Mol Sci. 2013;14(9):18488-501.

20. Bowler P. A clinical algorithm for wound biofilm identification. Journal of wound care. 2014;23(3);203.

21. Dowsett C. Biofilms: A practice-based approach to identification and treatment. Wounds UK. 2013;9(2).

22. Dou JL. New Is Old, and Old Is New: Recent Advances in Antibiotic-Based, Antibiotic-Free and Ethnomedical Treatments against MethicillinResistant Staphylococcus aureus Wound Infections. Int J Mol Sci. 2016;17(5):617.

23. Gawande PV, Leung KP, Madhyastha S. Antibiofilm and Antimicrobial Efficacy of DispersinB®-KSL-W Peptide-Based Wound Gel Against Chronic Wound Infection Associated Bacteria. Curr Microbiol; 2014:1-7.

24. Siddiqui AR, Bernstein JM. Chronic wound infection: facts and controversies. Clin Dermatol. 2010;28(5):519-26.

25. Hurlow J, Bowler PG. Potential implications of biofilm in chronic wounds: a case series. J Wound Care. 2012;21(3):109-110,112,114.

26. James GA. Biofilms in chronic wounds. Wound Repair Regen. 2008;16(1):37-44.

27. Wolcott R, Dowd S. The role of biofilms: are we hitting the right target? Plast Reconstr Surg. 2011;127(1): 28S-35S

28. Hess CT, Kirsner RS. Understanding the Presence of Biofilms in Wound Healing: Opportunities for Intervention, Today's Wound Clinic; 2012.

29. Park E. Staphyloccocus aureus Biofilms Impair Reepithelialization and Granulation Tissue Deposition in Cutaneous Wounds via a MyD88Dependent Mechanism. Plastic Reconstruct Surg. 2014;133(3s): 155 .

30. Gotz F. Staphylococcus and biofilms. Mol Microbiol. 2002;43(6):1367-78.

31. Boda SK. Cytotoxicity of Ultrasmall Gold Nanoparticles on Planktonic and Biofilm
Encapsulated Gram-Positive Staphylococci. Small. 2015;11(26):3183-93.

32. Wojtyczka RD. Biofilm Formation and Antimicrobial Susceptibility of Staphylococcus epidermidis Strains from a Hospital Environment. Int J Environ Res Public Health. 2014;11(5):4619-33.

33. Otto M. Staphylococcus epidermidis-the accidental pathogen. Nat Rev Microbiol. 2009;7(8):555-67.

34. Thant P. Microbial Colonization of Intravascular Catheters Inserted in Newborn Babies: A Descriptive Study. Clin Pediatr. 2016;1(1000108):2.

35. O'Gara JP, Humphreys H. Staphylococcus epidermidis biofilms: importance and implications. J Med Microbiol. 2001;50(7):582-7.

36. Mack D. The intercellular adhesin involved in biofilm accumulation of Staphylococcus epidermidis is a linear beta-1, 6-linked glucosaminoglycan: purification and structural analysis. $\mathbf{J}$ Bact. 1996;178(1):175-83.

37. Stevens NT, Greene CM, O'Gara JP, Humphreys H. Biofilm characteristics of Staphylococcus epidermidis isolates associated with device-related meningitis. J Med Microbiol. 2009;58:855-62.

38. Heilmann C, Schweitzer O, Gerke C, Vanittanakom N, Mack D, Gotz F. Molecular basis of intracellular adhesion in biofilm-forming Staphylococcus epidermidis. Mol Microbiol. 1996;20(5):1083-91.

39. Ngo QD, Vickery K, Deva AK. The effect of topical negative pressure on wound biofilms using an in vitro wound model. Wound Repair Regen. 2012;20(1):8390.

40. Scali C, Kunimoto B. An update on chronic wounds and the role of biofilms. Journal of cutaneous medicine and surgery. 2012;17(6):371-6.

41. Price LB. Macroscale spatial variation in chronic wound microbiota: a cross-sectional study. Wound Repair Regen. 2011;19(1):80-8.

42. Diemond-Hernandez B, Solorzano-Santos F, LeanosMiranda B, Peregrino-Bejarano L, Miranda-Novales G. Production of icaADBC-encoded polysaccharide intercellular adhesin and therapeutic failure in pediatric patients with Staphylococcal device-related infections. BMC Infect Dis. 2010;10:68.

43. Ziebuhr W, Krimmer V, Rachid S, Lössner I, Götz F, Hacker J. A novel mechanism of phase variation of virulence in Staphylococcus epidermidis: evidence for control of the polysaccharide intercellular adhesin synthesis by alternating insertion and excision of the insertion sequence element IS256. Mol Microbiol. 1999;32(2):345-56.

44. Rhoads DD. Clinical identification of bacteria in human chronic wound infections: culturing vs. $16 \mathrm{~S}$ ribosomal DNA sequencing. BMC Infect Dis. 2012;12:321.

45. Gardner SE. The neuropathic diabetic foot ulcer microbiome is associated with clinical factors. Diabetes. 2013;62(3):923-30.

46. Kozitskaya S. Clonal analysis of Staphylococcus epidermidis isolates carrying or lacking biofilm- 
mediating genes by multilocus sequence typing. J Clin Microbiol. 2005;43(9):4751-7.

47. Galdbart JO. Screening for Staphylococcus epidermidis markers discriminating between skinflora strains and those responsible for infections of joint prostheses. J Infect Dis. 2000;182(1):351-5.

48. Cole SJ. Catheter-Associated Urinary Tract Infection by Pseudomonas aeruginosa is mediated by Exopolysaccharide-Independent Biofilms. Infection and immunity. 2014;82(5):2048-58.

49. Han A. The importance of a multifaceted approach to characterizing the microbial flora of chronic wounds. Wound Repair Regen. 2011;19(5):532-41.
50. Frank KL. In vitro effects of antimicrobial agents on planktonic and biofilm forms of Staphylococcus lugdunensis clinical isolates. Antimicrob Agents Chemother. 2007;51(3):888-95.

Cite this article as: Hussain MA, Rathnayake IU, Huygens F. Prevalence of biofilm controlling ica genes of Staphylococcus epidermidis detected in healthy skin, blood samples from septicaemia patients and chronic wounds. Int J Basic Clin Pharmacol 2017;6:726-33. 